\title{
CORETAN TEMBANG PURNOMO
}

\author{
Nur Istiqomah
}

Universitas Nahdlatul Ulama Sidoarjo

\section{PENDAHULUAN}

Arti yang tepat dari kata puisi telah mengalami banyak perubahan dari waktu ke waktu. Kata puisi berasal dari bahasa Yunani dan aslinya berarti penciptaan. Karena itu, dalam arti luas, ini merujuk pada penciptaan semua teks sastra. Jadi apa yang kita sebut literatur saat ini. Puisi, dalam bahasa umum, adalah istilah yang digunakan untuk menggambarkan puisi dan ekspresi seperti yang ditemukan dalam album puisi. Di Jerman, Hari Puisi Sedunia telah diselenggarakan sejak tahun 2000 pada tanggal 21 Maret dan diprakarsai oleh UNESCO. Tujuan hari puisi adalah untuk menjadi memori puisi, seperti yang dilupakan hari ini. Pada saat yang sama terjadi 
pertukaran antarbudaya. Sekolah memotivasi anak-anak untuk menulis puisi mereka sendiri hari itu (Grosdidier, 2019).

Puisi, atau "puisi" adalah istilah dari bahasa Yunani dan mengacu pada jenis seni yang menggunakan imajinasi dengan kemungkinan bahasa yang ekspresif untuk membawa kehidupan pendengar atau pembaca, pengalaman dunia dan interpretasi lebih dekat. Pada permulaannya, puisi menyampaikan kepercayaan religius dan mitos terutama dalam bentuk gambar yang ritmis, seperti dalam epik Gilgames atau dalam Mazmur. Dari awal kebudayaan manusia, nyanyian pujian, doa, narasi mitos-epik, nyanyian pujian dan perkataan telah bertahan sebagai ungkapan puitis. Puisi menggunakan bentuk eksternal dan internal dalam bahasa dan dengan demikian berbeda dari prosa bahasa sehari-hari. Sebagai alat cetakan, puisi menggunakan ritme, meter, sajak (sajak bar dan sajak akhir), bait, paralelisme frasa, desain komposisi yang berani dan bebas, dan juga 
pernyataan simbolis terutama seperti parafrase, gambar, perumpamaan, dan metafora. Lebih dari seni lainnya, puisi berfokus pada pikiran dan jiwa manusia untuk mendapatkan emosi, untuk merangsang imajinasi pendengar atau pembaca, untuk menyentuh jiwa mereka dan mengubah mereka (Die-poesie, 2019).

Puisi, yaitu, sastra yang ditulis dalam rima atau ayat, muncul pertama kali setelah Perang Makedonia antara Kekaisaran Romawi dan Makedonia pada abad ke-3 dan ke-2 SM. Berlangsung di atas budak-budak Yunani ke Roma. Karena di Roma sendiri, tidak ada budaya penulisan yang canggih seperti halnya di Yunani. Maka pada awal sastra Latin berdiri seorang pembebasan Yunani bernama Livius Andronicus (meninggal sekitar 200 SM), yang menerjemahkan karya-karya Yunani ke dalam bahasa Latin, dan terutama puisi, yaitu epos, tragedi dan komedi. Dia menerjemahkan u.a. Odyssey karya Homer dalam bahasa Latin, yang sekarang disebut Odusia. Ada 
tiga periode utama dalam sastra Latin: pra-klasik, klasik, dan pasca-klasik (Sofatutor, 2019).

\section{PENULIS PUISI}

Salah satu penulis puisi adalah Agung Purnomo. Penyair ini tumbuh dan besar di Sidoarjo, Jawa Timur. Berikut tulisan syair beliau telah disebarkan secara luas melalui penerbit nasional, yaitu: STIEBA Madura Press, dan UNUSIDA Press. 


\section{Tabel 1. Tembang Karya Agung Purnomo}

\begin{tabular}{|c|c|c|c|c|c|c|}
\hline No & $\begin{array}{l}\text { Judul } \\
\text { Puisi } \\
\end{array}$ & $\begin{array}{l}\text { Jenis } \\
\text { puisi }\end{array}$ & Penulis & $\begin{array}{l}\text { Judul } \\
\text { buku }\end{array}$ & Penerbit & Tahun \\
\hline 1 & Pandai & $\begin{array}{c}\text { Puisi } \\
\text { Riddle }\end{array}$ & $\begin{array}{c}\text { Agung } \\
\text { Purnomo, } \\
\text { Nur Asitah }\end{array}$ & $\begin{array}{c}\text { Tolesan } \\
\text { Aditi }\end{array}$ & $\begin{array}{c}\text { STIEBA } \\
\text { Madura } \\
\text { Press }\end{array}$ & 2019 \\
\hline 2 & $\begin{array}{c}\text { Sepekan } \\
\text { Awal } \\
\text { Tanpamu }\end{array}$ & $\begin{array}{c}\text { Puisi } \\
\text { bersekuen }\end{array}$ & $\begin{array}{c}\text { Agung } \\
\text { Purnomo, } \\
\text { Nur Asitah }\end{array}$ & $\begin{array}{c}\text { Arebhan } \\
\text { Helai }\end{array}$ & $\begin{array}{c}\text { STIEBA } \\
\text { Madura } \\
\text { Press }\end{array}$ & 2019 \\
\hline 3 & Berpulang & $\begin{array}{l}\text { Puisi } \\
\text { epitaf }\end{array}$ & $\begin{array}{c}\text { Agung } \\
\text { Purnomo }\end{array}$ & $\begin{array}{c}\text { Syair } \\
\text { Nimala }\end{array}$ & $\begin{array}{c}\text { STIEBA } \\
\text { Madura } \\
\text { Press }\end{array}$ & 2019 \\
\hline 4 & $\begin{array}{c}\text { Bapak } \\
\text { Samsuri }\end{array}$ & $\begin{array}{c}\text { Puisi } \\
\text { Clerihew }\end{array}$ & $\begin{array}{c}\text { Agung } \\
\text { Purnomo, } \\
\text { Nur Asitah }\end{array}$ & $\begin{array}{c}\text { Dhalubang } \\
\text { Marta }\end{array}$ & $\begin{array}{c}\text { STIEBA } \\
\text { Madura } \\
\text { Press }\end{array}$ & 2019 \\
\hline 5 & Dua Kaki & $\begin{array}{l}\text { Puisi } \\
\text { Bebas }\end{array}$ & $\begin{array}{c}\text { Agung } \\
\text { Purnomo }\end{array}$ & $\begin{array}{l}\text { Kidung } \\
\text { Nawala } \\
\text { (Jilid 2) }\end{array}$ & $\begin{array}{c}\text { UNUSIDA } \\
\text { Press }\end{array}$ & 2018 \\
\hline 6 & Tangisnya & $\begin{array}{c}\text { Puisi } \\
\text { Naratif }\end{array}$ & $\begin{array}{c}\text { Agung } \\
\text { Purnomo, } \\
\text { Nur Asitah }\end{array}$ & $\begin{array}{c}\text { Bhumi } \\
\text { Bawera }\end{array}$ & $\begin{array}{c}\text { STIEBA } \\
\text { Madura } \\
\text { Press }\end{array}$ & 2019 \\
\hline 7 & Cantik & $\begin{array}{c}\text { Puisi } \\
\text { Jenaka } \\
\text { Limerick }\end{array}$ & $\begin{array}{c}\text { Agung } \\
\text { Purnomo, } \\
\text { Nur Asitah } \\
\end{array}$ & $\begin{array}{c}\text { Lembhar } \\
\text { Jiwana }\end{array}$ & $\begin{array}{c}\text { STIEBA } \\
\text { Madura } \\
\text { Press } \\
\end{array}$ & 2019 \\
\hline 8 & \#CH1 & $\begin{array}{l}\text { Puisi } \\
\text { Bebas }\end{array}$ & $\begin{array}{c}\text { Agung } \\
\text { Purnomo }\end{array}$ & $\begin{array}{l}\text { Kidung } \\
\text { Nawala } \\
\text { (Jilid 1) }\end{array}$ & $\begin{array}{l}\text { UNUSIDA } \\
\text { Press }\end{array}$ & 2018 \\
\hline 9 & Menyala & $\begin{array}{l}\text { Puisi } \\
\text { Haiku }\end{array}$ & $\begin{array}{c}\text { Agung } \\
\text { Purnomo }\end{array}$ & $\begin{array}{c}\text { Tenta } \\
\text { Kimaya }\end{array}$ & $\begin{array}{c}\text { STIEBA } \\
\text { Madura } \\
\text { Press }\end{array}$ & 2019 \\
\hline 10 & $\begin{array}{l}\text { Rindu di } \\
\text { Ubun- } \\
\text { Ubun }\end{array}$ & $\begin{array}{l}\text { Puisi } \\
\text { Bebas }\end{array}$ & $\begin{array}{c}\text { Agung } \\
\text { Purnomo }\end{array}$ & $\begin{array}{c}\text { Rassana } \\
\text { Jlantir }\end{array}$ & $\begin{array}{c}\text { STIEBA } \\
\text { Madura } \\
\text { Press }\end{array}$ & 2019 \\
\hline 11 & Kita & $\begin{array}{l}\text { Puisi } \\
\text { Bebas }\end{array}$ & $\begin{array}{l}\text { Agung } \\
\text { Purnomo, } \\
\text { Elsa } \\
\text { Rosyidah }\end{array}$ & $\begin{array}{l}\text { Suweda } \\
\text { Ate }\end{array}$ & $\begin{array}{l}\text { STIEBA } \\
\text { Madura } \\
\text { Press }\end{array}$ & 2019 \\
\hline
\end{tabular}




\section{RESENSI}

Tembang-tembang karya Agung Purnomo diantaranya yakni: pandai (Purnomo \& Asitah, 2019c), dan kita (Purnomo \& Rosyidah, 2019), rindu di ubun-ubun (Purnomo, 2019c), sepekan awal tanpamu (Purnomo \& Asitah, 2019d), \#CH1 (Purnomo, 2018a), cantik (Purnomo \& Asitah, 2019b), berpulang (Purnomo, 2019a), dua kaki (Purnomo, 2018b), bapak Samsuri (Purnomo \& Asitah, 2019a), menyala (Purnomo, 2019b), dan tangisnya (Purnomo \& Asitah, 2019e).

Puisi diterbitkan pada periode tahun 2018 dan tahun 2019. Agung Purnomo menulis sebelas puisi dengan gaya epitaf, clerihew, bebas, riddle, bersekuen, jenaka limerik dan haiku. Puisi karya Purnomo tergolong ringan, gampang dipahami dan sederhana bagi pembaca dan penikmat seni. 


\section{REFERENCES}

Die-poesie. (2019). Was ist Poesie ?. Retrieved June 20, 2019, from http://www.diepoesie.de/poesie.htm

Grosdidier, S. (2019). Poesie: Bedeutung und Definition. Retrieved June 25, 2019, from https://praxistipps.focus.de/poesiebedeutung-und-definition_107987

Purnomo, A. (2018a). \#CH1. In Kidung Nawala (Jilid 1). Sidoarjo: UNUSIDA Press.

Purnomo, A. (2018b). Dua Kaki. In Kidung Nawala (Jilid 2). Sidoarjo: UNUSIDA Press.

Purnomo, A. (2019a). Berpulang. In Syair Nimala.

Sumenep: STIEBA Madura Press.

Purnomo, A. (2019b). Menyala. In Tenta Kimaya.

Sumenep: STIEBA Madura Press.

Purnomo, A. (2019c). Rindu di Ubun-Ubun. In

Rassana Jlantir. Sumenep: STIEBA Madura Press.

Purnomo, A., \& Asitah, N. (2019a). Bapak Samsuri.

In Dhalubang Marta. Sumenep: STIEBA

Madura Press.

Purnomo, A., \& Asitah, N. (2019b). Cantik. In

Lembhar Jiwana. Sumenep: STIEBA Madura

Press.

Purnomo, A., \& Asitah, N. (2019c). Pandai. In

Tolesan Aditi. Sumenep: STIEBA Madura

Press. 
Purnomo, A., \& Asitah, N. (2019d). Sepekan Awal Tanpamu. In Arebhan Helai. Sumenep: STIEBA Madura Press.

Purnomo, A., \& Asitah, N. (2019e). Tangisnya. In

Bhumi Bawera. Sumenep: STIEBA Madura Press.

Purnomo, A., \& Rosyidah, E. (2019). Kita. In

Suweda Ate. Sumenep: STIEBA Madura Press.

Sofatutor. (2019). Dichtung. Retrieved June 29,

2019, from

https://www.sofatutor.com/latein/autorenund-werke/dichtung 